\begin{tabular}{|c|c|}
\hline $\begin{array}{l}\text { Univerzitet u Beogradu } \\
\text { Poljoprivredni fakultet } \\
\text { Institut za poljoprivrednu tehniku }\end{array}$ & $\begin{array}{r}\text { University of Belgrade } \\
\text { Faculty of Agriculture } \\
\text { Institute of Agricultural Engineering }\end{array}$ \\
\hline $\begin{array}{l}\text { Naučni časopis } \\
\text { POLJOPRIVREDNA TEHNIKA }\end{array}$ & $\begin{array}{r}\text { Scientific Journal } \\
\text { AGRICULTURAL ENGINEERING }\end{array}$ \\
\hline $\begin{array}{l}\text { Godina XLVI } \\
\text { Broj } 4 ., 2021 . \\
\text { Strane: } 84-96\end{array}$ & $\begin{array}{r}\text { Year XLVI } \\
\text { No. 4., } 2021 . \\
\text { pp: } 84-96 \\
\end{array}$ \\
\hline
\end{tabular}

\title{
PERFORMANCE EVALUATION OF A MOTORIZED GINGER RHIZOMES PEELING MACHINE
}

\author{
Chimdi Godswill Arocha*1, Kayode Joshua Simonyan ${ }^{1}$, Tosin Paul ${ }^{1}$ \\ ${ }^{1}$ Department of Agricultural and Bioresources Engineering \\ Michael Okpara University of Agriculture, Umudike, Abia State, Nigeria.
}

\begin{abstract}
A $5 \mathrm{~kg}$ motorized Ginger rhizome (Zingiber Officinale Roscoe) peeling machine was designed, developed and tested. Three moisture contents $(70 \%, 75 \%$ and $80 \% \mathrm{wb})$, three feed rates $(54 \mathrm{~kg} / \mathrm{h}, 68 \mathrm{~kg} / \mathrm{h}$ and $73 \mathrm{~kg} / \mathrm{h})$ and three peeling speeds $(230$ $\mathrm{rpm}, 270 \mathrm{rpm}$ and $300 \mathrm{rpm}$ ) were used for the performance evaluation of the machine. A $3 \times 3 \times 3$ factorial experiment in a randomized complete block design (RCBD); replicated two times was used to study the effects and interactions of the three factors (moisture content, feed rates and peeling speed) on the performance parameters (peeling efficiency, peeling capacity and percent damage). Relationship between performance parameters and the influencing factors were determined using multilevel factorial design and response surface methodology for the graphical analyses. The study showed that peeling efficiency increased from $82.3 \%$ to $88.5 \%$ with an increase in moisture content from $70 \%$ to $80 \%$, a decrease in feed rate from $73 \mathrm{~kg} / \mathrm{h}$ to $54 \mathrm{~kg} / \mathrm{h}$ and an increase in peeling speed from $230 \mathrm{rpm}$ to $300 \mathrm{rpm}$. Peeling capacity increased from $2.4 \mathrm{~kg} / \mathrm{h}$ to 11.64 $\mathrm{kg} / \mathrm{h}$ with an increase in moisture content from $70 \%$ to $80 \%$, a decrease in feed rate from $73 \mathrm{~kg} / \mathrm{h}$ to $54 \mathrm{~kg} / \mathrm{h}$ and an increase in peeling speed from $230 \mathrm{rpmto} 300 \mathrm{rpm}$. Percent damage increased from $6.3 \%$ to $14.4 \%$ with a decrease in moisture content from $80 \%$ to $70 \%$, an increase in feed rate from $54 \mathrm{~kg} / \mathrm{h}$ to $73 \mathrm{~kg} / \mathrm{h}$ and an increase in peeling speed from $230 \mathrm{rpm}$ to $300 \mathrm{rpm}$. The analysis of variance (ANOVA) result showed that the interaction of moisture content, feed rate and peeling speed had significant effect on peeling efficiency, peeling capacity and percent damage at $p<0.05$ level. For a maximum peeling efficiency, peeling capacity and minimum percent damage, an optimum moisture content of $75 \%$, feed rate of $68 \mathrm{~kg} / \mathrm{h}$ and peeling speed of $270 \mathrm{rpm}$ were recommended for use.
\end{abstract}

Key words: Ginger rhizomes, performance evaluation, peeling capacity, peeling efficiency.

*Corresponding Author. E-mail: arochachimdi@gmail.com 


\section{INTRODUCTION}

Peeling of Ginger (Zingiber Officinale Roscoe) is an important unit operation where fully matured rhizomes are scraped with bamboo-splits having pointed ends, to remove the outer skin before drying to accelerate the drying process [1]. Although Ginger cultivation in Nigeria started in 1927 [2]. Peeling which is one of the unit operations in its local processing is still being done predominantly by traditional method (manual scraping with knife) which is labour intensive, full of drudgery and it equally exposes the hand to injury. Primary processing of Ginger rhizomes involves operations such as washing, slicing/splitting/peeling and drying [3]. Dried Ginger is produced from mature rhizome, since the flavour and aroma become much stronger as the rhizome matures. Rhizomes of dried Ginger may be left whole, peeled, split or sliced into smaller pieces to speed up drying [4]. Deep scraping with knife needs to be avoided to prevent damage to oil-bearing cells present just beneath the outer skin. Excessive peeling results in reduction of essential oil content in dried product [4]. Few industries that process Ginger in the country make use of imported machinery due to non-availability of simple locally developed machines for its processing and this has adversely affected the production and marketing of Ginger in Nigeria, in spite of its great economic potentials.

[1] developed a concentric drum brush type Ginger peeler with a capacity to peel 7 $\mathrm{kg}$ per batch. The optimum operating conditions for peeling Ginger were obtained at drum load of $7 \mathrm{~kg}$, for inner drum speed of $45 \mathrm{rpm}$, outer drum speed of $20 \mathrm{rpm}$ and for a peeling duration of 15 minutes. The peeling efficiency was $61 \%$ and the corresponding material loss was $5.33 \%$. A brush type Ginger peeling machine with two continuous brush belts moving vertically in opposite direction was reported by [5]. The maximum peeling efficiency obtained for the brush type Ginger peeling machine was $84.3 \%$ at a belt speed of $85 \mathrm{rpm}$ having a belt spacing of $1 \mathrm{~cm}$. [6] reported the development of an abrasive brush type Ginger peeling machine consisting of two continuous vertical belts provided with 32gauge steel wire brush, $2 \mathrm{~cm}$ long and having a peeling zone of $135 \mathrm{~cm}$, had a maximum peeling efficiency of $85 \%$.

Despite all the developments relating to Ginger peeling machine, the farmers still fall back to the manual method of peeling. In recognition of the constraints imposed by manual method of peeling Ginger, there is need to develop a motorized Ginger peeling machine that will be developed locally. This study therefore reports on the performance evaluation of a locally developed motorized Ginger rhizomes peeling machine.

\section{MATERIALS AND METHODS}

The study was conducted at the Postharvest Technology Laboratory, Department of Agricultural and Bioresources Engineering, Michael Okpara University of Agriculture, Umudike, Abia State, Nigeria. 


\section{Description of Developed Ginger Rhizome Peeling Machine}

The motorized Ginger peeling machine consist of the following components: frame, feeding unit, pulley and belt drive, shoe pad, arm, shaft, crank shaft, cranking mechanism, discharge chute and gate. Figures 1 and 2 shows the pictorial and isometric views of the developed motorized Ginger rhizomes peeling machine.

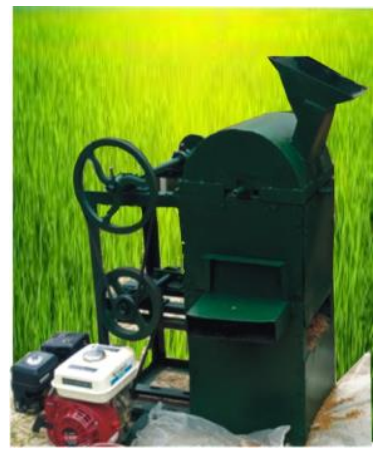

Fig. 1. Developed Ginger rhizomes peeling machine

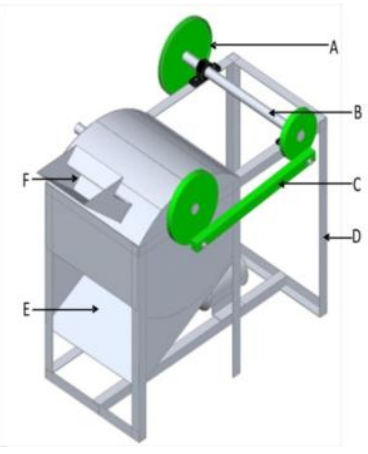

Fig. 2. Isometric view of the developed ginger rhizomes peeling machine Legend: A-Puley, B-Puley shaft, C-Connecting rod, D-Frame, E-Discharge shute, F-Hopper, G-Shoe pad shaft, H- Discharge gate

\section{Frame}

The frame holds all the components of the Ginger peeling device. It is designed to withstand torsional and vibrational forces. It has a length of $800 \mathrm{~mm}$, width of $400 \mathrm{~mm}$ and a height of $830 \mathrm{~mm}$.

\section{Feeding unit (Hopper)}

The hopper feeds the Ginger rhizomes into the peeling chamber where rhizomes are subjected to abrasive force from the abrasive shoe pad through the shaft rotation. It has a dimension of $300 \mathrm{~mm}$ by $230 \mathrm{~mm}$ and inclined at an angle of $40^{\circ}$.

\section{Pulley and belt drive}

The pulleys which have diameter sizes of $85 \mathrm{~mm}, 250 \mathrm{~mm}$ and $300 \mathrm{~mm}$ transmits the mechanical energy from the shaft of the combustion engine to the shaft of the Ginger rhizome peeler.

\section{Shoe pad}

This is a not machine component that comes into direct contact with the Ginger rhizomes and provides the frictional force for peeling. The shoe pad (362 mm by $118 \mathrm{~mm}$ ) is made-up of wire gauze material which has a rough surface. This material is attached to a flat bar using bolts and nuts for ease of replacement. 


\section{Arm}

The arm is the component of the machine which carries the shoe pad for the peeling. It is joined to the shaft by welding. It has a hollow pipe which is welded to the shaft and then a solid part which slides inside the hollow pipe in order to alter the clearance. The solid arm (200 mm length and $10 \mathrm{~mm}$ diameter) is held firmly to the hollow pipe by screw after adjusting to the suitable clearance. The adjustment is to accommodate for the variation in the sizes of the Ginger rhizomes.

\section{Shaft}

The shaft of the Ginger rhizome peeling machine which has a length of $620 \mathrm{~mm}$ and a diameter of $25 \mathrm{~mm}$ transmits the mechanical energy that will be transmitted from the combustion engine through the pulley and belt drive system to the oscillating shoe pad.

\section{Connecting rod}

This transmits rotary motion given to the shaft by the motor to oscillating motion of the shoe pad which has a length of $480 \mathrm{~mm}$ and diameter of $15 \mathrm{~mm}$.

\section{Discharge chute}

Discharge chute is an extension of the peeling unit whereby the peels of the Ginger rhizomes are discharged under gravity as they are being peeled. It has a dimension of 115 $\mathrm{mm}$ length, $300 \mathrm{~mm}$ width and an angle of inclination of $65^{\circ}$.

\section{Discharge gate}

The discharge gate is a casing of $80 \mathrm{~mm}$ length and $305 \mathrm{~mm}$ width covering the peeling chamber which is inclined at an angle of $46^{0}$ so that during the peeling operation the rhizomes do not splatter, rather its being opened after the operation for collection of the peeled Ginger rhizomes.

\section{Working Principle of the Developed Ginger Peeling Machine}

The kinematics upon which the machine works is the principle of quadric-crank mechanism. This principle converts rotary motion to oscillatory motion, whereas the force application for peeling uses the principle of attrition or shearing force principle. The shoe pad which comes in contact with the Ginger has conical projection on its surface. The machine prime mover is a $2.25 \mathrm{~kW}$ petrol internal combustion engine. The shoe pad is attached to an adjustable arm which is then attached to the shaft. The shaft is connected to the cranking mechanism through a connecting rod. As the pulley makes a rotary motion, this motion is converted to the oscillatory motion of the shaft, the arm and the shoe pad which are attached rigidly together. The shoe pad and the peeling chamber have a clearance which depends on the geometric mean diameter of the Ginger rhizomes. As the rhizomes are trapped in between the abrasive shoe pad and the abrasive peeling chamber; and the shoe pad performs an oscillating motion, the rhizomes are being peeled due to the friction between the Ginger and the abrasive surface of peeling chamber; Ginger and abrasive surface of the shoe pad and as well friction among the rhizomes. The peels fall through the openings on the peeling chamber through the discharge chute while the peeled Ginger rhizomes are collected from the discharge gate. 


\section{Experimental Procedure}

Ginger rhizomes used for this study was sourced from Ntigha market in Isialangwa Local Government Area of Abia State, Nigeria. The rhizomes were cleaned and prepared ready for peeling. The machine was set into operation and allowed for 2 minutes before a known weight of Ginger rhizomes were fed into the peeling chamber through the hopper. The time taken together with the peeling shaft speed were noted and recorded. The peeled Ginger and peels were collected and weighed independently. The feed rate and moisture content were also determined. Each test carried out was replicated two times and at three levels of speed, moisture content and feed rate. The peeling speed, feed rate and moisture content were taken as independent parameters for this study. Three levels of peeling speed termed $S_{1}, S_{2}$ and $S_{3}(230,270$ and $300 \mathrm{rpm})$ were chosen in order to determine the optimum speed required for peeling Ginger rhizomes. Three levels of feed rate were also taken as $F_{1}, F_{2}$ and $F_{3}(54,68$ and $73 \mathrm{~kg} / \mathrm{h})$. Also, three levels of moisture content were taken as $\mathrm{M}_{1}, \mathrm{M}_{2}$ and $\mathrm{M}_{3}(70,75$ and $80 \% \mathrm{wb})$. These parameters gave a $3 \times 3 \times 3$ factorial experiment replicated two times. This gave a total of 27 treatment combinations and 54 numbers of observations. The values obtained were used to calculate the performance parameters.

\section{Performance Evaluation Parameters}

The performance evaluation carried out on the developed Ginger peeling machine was assessed using the following parameters given by [6]:

$$
F_{R}=\frac{Q_{f}}{t}
$$

Where,

$\mathrm{F}_{\mathrm{R}}=$ feed rate $(\mathrm{kg} / \mathrm{h})$

$\mathrm{Q}_{\mathrm{f}}=$ mass of Ginger rhizomes fed into the machine $(\mathrm{kg})$

$\mathrm{t}=$ time to finish the feeding $(\mathrm{h})$

$\eta_{p}=\frac{\left(W_{s f}-W_{s m}\right)}{W_{s f}} \times 100 \%$

Where,

$\eta_{\mathrm{p}}=$ peeling efficiency of Ginger peeler $(\%)$

$W_{s f}=$ weight of skin on fresh Ginger $(\mathrm{kg})$

$W_{s m}=$ weight of skin removed by hand trimming after mechanical peeling $(\mathrm{kg})$

$C_{p}=\frac{Q_{t}}{t}$

Where,

$C_{p}=$ peeling capacity $(\mathrm{kg} / \mathrm{h})$

$\mathrm{Q}_{\mathrm{t}}=$ mass of Ginger rhizome peeled $(\mathrm{kg})$

$\mathrm{t}=$ time taken for peeling $(\mathrm{h})$

$$
P_{d}=\frac{\left(W_{1}-W_{s f}\right)-\left(W_{2}-W_{s m}\right)}{W_{1}} \times 100 \%
$$

Where,

$P_{d}=$ damage of Ginger $(\%)$

$\mathrm{w}_{1}=$ total weight of Ginger before peeling $(\mathrm{kg})$

$\mathrm{w}_{2}=$ total weight of Ginger after mechanical peeling $(\mathrm{kg})$

$W_{s f}=$ weight of skin on fresh Ginger $(\mathrm{kg})$

$W_{s m}=$ weight of skin removed by hand trimming after mechanical peeling $(\mathrm{kg})$ 


\section{Statistical analysis}

Data obtained during performance evaluation of the machine were subjected to the Analysis of Variance (ANOVA) for the test of significance of experimental factors and their interactions. ANOVA for each factor was done using Minitab version 17.0 software package and a significance level of $(\mathrm{P}<0.05)$ was used for all the analyses. Relationship between performance parameters and the influencing factors were determined using multilevel factorial design and response surface methodology for the graphical analyses.

\section{RESULTS AND DISCUSSION}

\section{Effect of Interaction of Experimental Factors on Peeling Efficiency}

Peeling efficiency as shown in Fig. 3 increased from $82.9 \%$ to $88.5 \%$ with an increase in feed rate and decrease in moisture content. According to Fig.4, peeling efficiency increased from $82.3 \%$ to $87.8 \%$ with a decrease in moisture content and an increase in peeling speed which could be as a result of the increased friction between the rhizomes. [1] reported a maximum Ginger peeling efficiency of $62.86 \%$ when the outer drum speed was $25 \mathrm{rpm}$, the inner drum speed was $45 \mathrm{rpm}$ and the peeling duration was 15 minutes at a constant drum load of $6 \mathrm{~kg}$ of Ginger. Also, the peeling efficiency decreased from $88.2 \%$ to $84.2 \%$ with an increase in feed rate and a decrease in peeling speed as shown in Fig. 5 . There was significant effect in the interaction of moisture content, feed rate and peeling speed on peeling efficiency at $\mathrm{p}<0.05$ level as presented in Table 1. [5] reported a maximum peeling efficiency of $84.3 \%$ in a vertical brush type Ginger peeling machine when the belt speed was $85 \mathrm{rpm}$ at belt spacing was $1 \mathrm{~cm}$. [7] reported that during abrasive peeling of potatoes in an abrasive drum type peeler, peeling efficiency increased with time. Similarly, peeling efficiency also increased with the increase in drum speed. This agrees with this study.

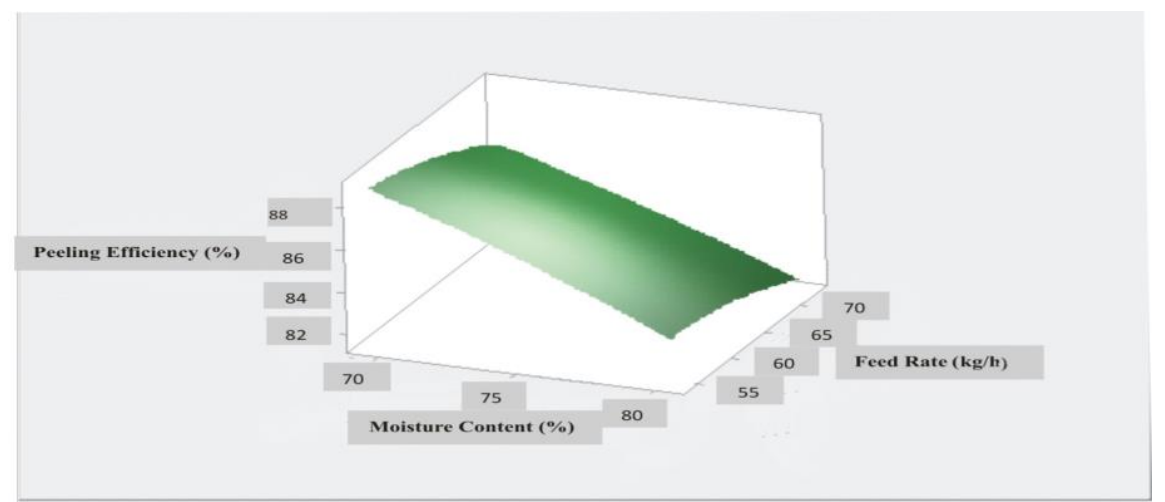

Fig. 3. Surface plot of interaction of moisture content and feed rate on peeling efficiency 


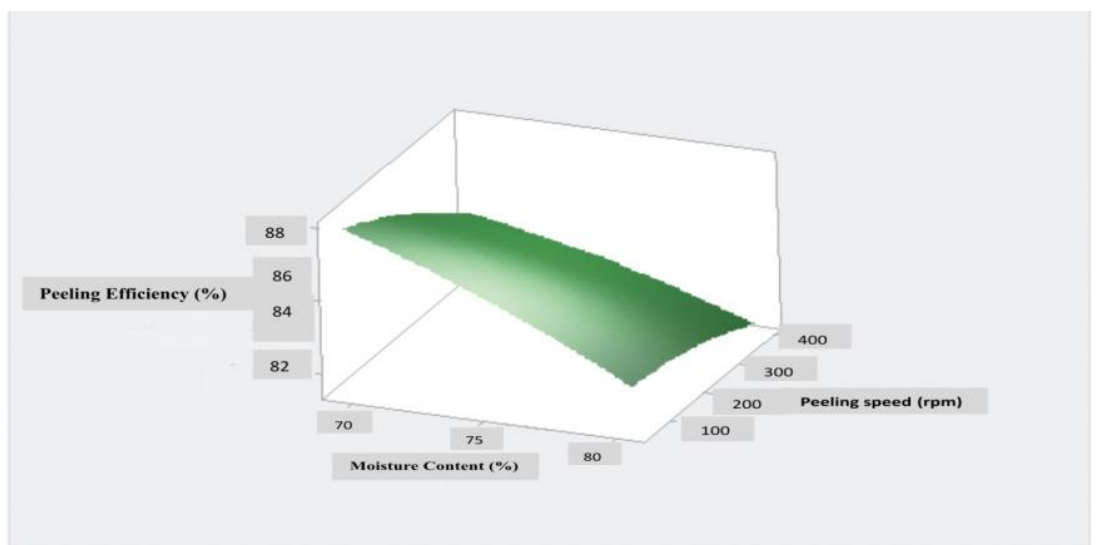

Fig. 4. Surface plot of interaction of moisture content and peeling speed on peeling efficiency

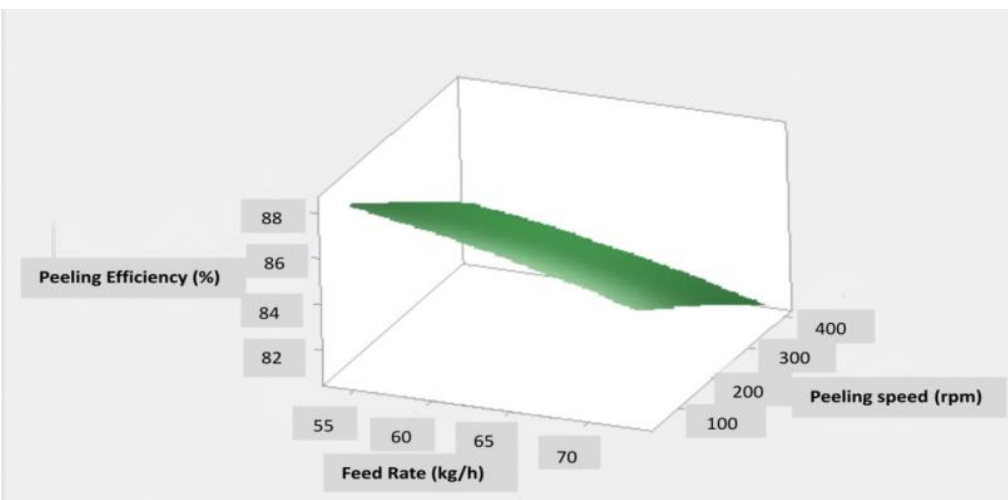

Fig. 5. Surface plot of interaction of feed rate and peeling speed on peeling efficiency

Tab 1. ANOVA for the effects of moisture content, feed rate and peeling speed on peeling efficiency

\begin{tabular}{|c|c|c|c|c|c|c|}
\hline $\begin{array}{l}\text { Source } \\
\text { Variation }\end{array}$ & of & DF & SS & MS & F-value & P-value \\
\hline $\mathrm{MC}$ & & 2 & 8.61 & 4.31 & 2.07 & $0.1458^{\mathrm{NS}}$ \\
\hline FR & & 2 & 18.32 & 9.16 & 4.40 & $0.02218^{\mathrm{NS}}$ \\
\hline PS & & 2 & 4.60 & 2.30 & 1.11 & $0.3441^{\mathrm{NS}}$ \\
\hline MC*FR & & 4 & 11.85 & 2.96 & 1.42 & $0.2542^{\mathrm{NS}}$ \\
\hline MC*PS & & 4 & 7.27 & 1.82 & 0.88 & $0.4889^{\mathrm{NS}}$ \\
\hline $\mathrm{FR} * \mathrm{PS}$ & & 4 & 7.97 & 1.99 & 0.96 & $0.4453^{\mathrm{NS}}$ \\
\hline MC*FR*PS & & 8 & 41.72 & 5.22 & 2.51 & $0.03507^{\mathrm{s}}$ \\
\hline Error & & 27 & 56.06 & 2.08 & & \\
\hline Total & & 53 & 156.71 & & & \\
\hline
\end{tabular}

Keynote:

MC - Moisture content; FR - Feed rate; PS - Peeling speed; DF- Degree of freedom; SS - Sum of squares; MS - Mean of squares; S - Significant; NS - Not significant 


\section{Effect of Interaction of Experimental Factors on Peeling Capacity}

Figure 6 showed that the peeling capacity increased from $9 \mathrm{~kg} / \mathrm{h}$ to $10.9 \mathrm{~kg} / \mathrm{h}$ with an increase in feed rate and a decrease in moisture content. The peeling capacity as well decreased from $7.2 \mathrm{~kg} / \mathrm{h}$ to $2.4 \mathrm{~kg} / \mathrm{h}$ with a decrease in moisture content and a decrease in peeling speed (Fig. 7) which was due to a decrease in friction among the rhizomes. Also, peeling capacity increased from $3.2 \mathrm{~kg} / \mathrm{h}$ to $9.8 \mathrm{~kg} / \mathrm{h}$ with an increase in peeling speed and decrease in feed rate (Fig. 8) which was due to the amount of Ginger fed into the machine and also increase in friction due to increase in speed. In Table 2, the analysis of variance (ANOVA) showed that the interaction of moisture content, feed rate and peeling speed had a highly significant difference on peeling capacity at $p<0.05$ level. [8] reported that the average throughput capacity of cocoa yam peeling machine was highest $(112.92 \mathrm{~kg} / \mathrm{h})$ at the operational speed of $933 \mathrm{rpm}$ which was the most efficient for the operation of the machine.

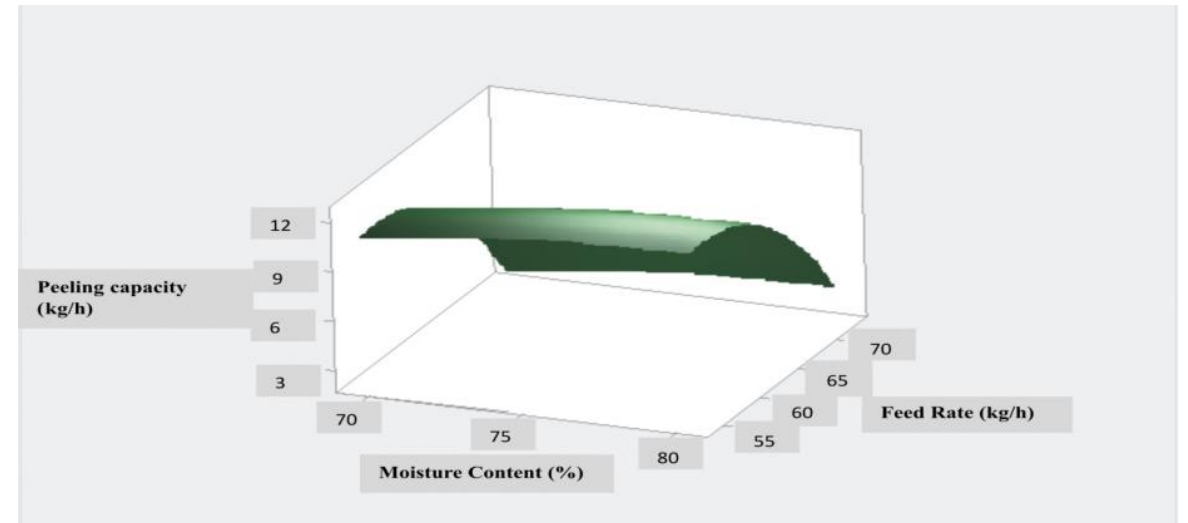

Fig. 6. Surface plot of interaction of moisture content and feed rate on peeling capacity

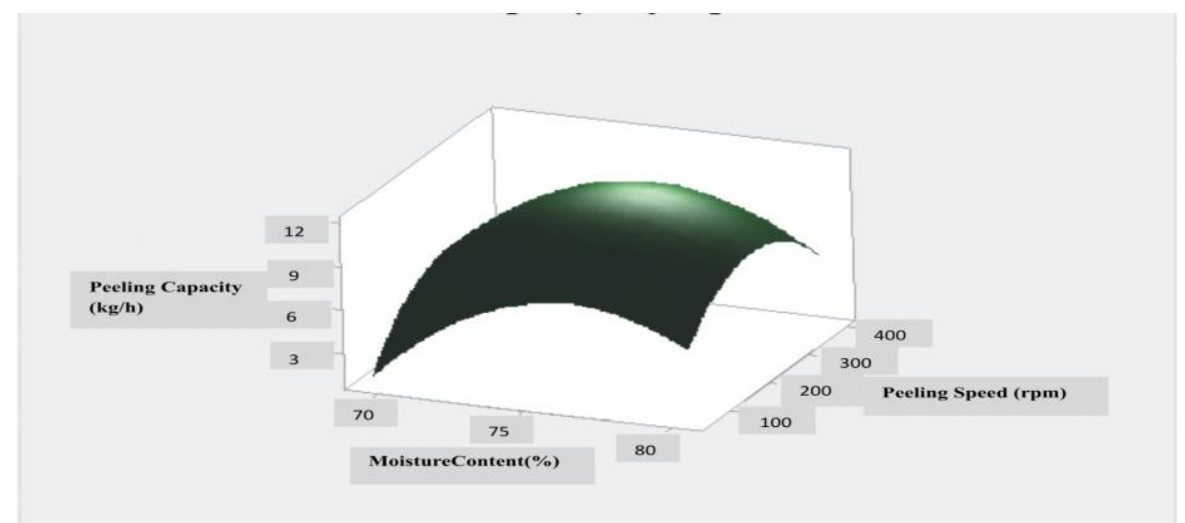

Fig. 7. Surface plot of interaction of moisture content and peeling speed on peeling capacity 


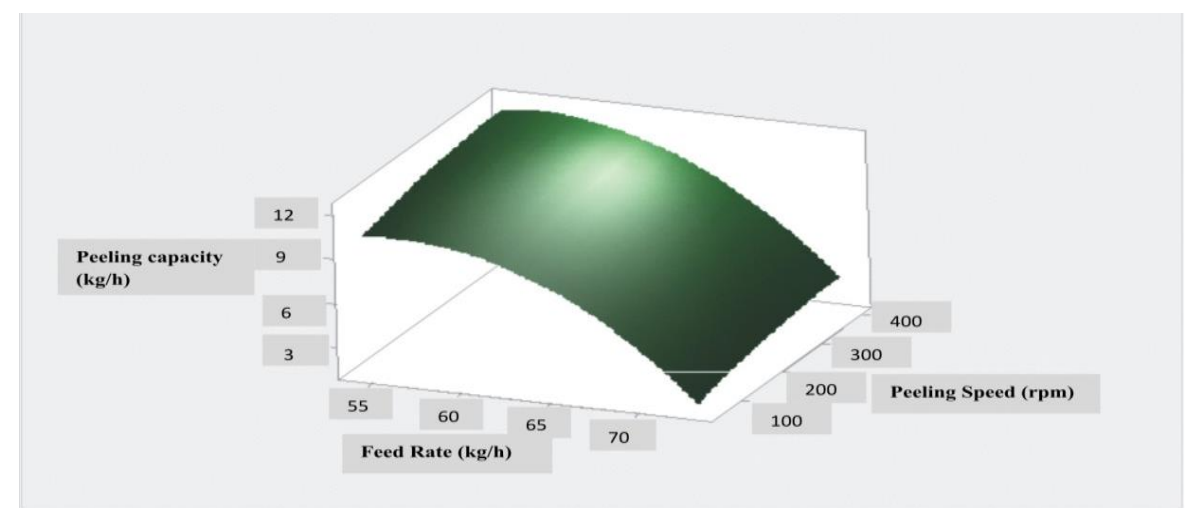

Fig. 8. Surface plot of interaction of feed rate and peeling speed on peeling capacity

Tab 2. ANOVA for the effects of moisture content, feed rate and peeling speed on peeling capacity

\begin{tabular}{l|cll|c|c}
\hline Source of Variation & DF & SS & MS & F-value & P-value \\
\hline MC & 2 & 0.60 & 0.30 & 115.38 & $0.00001^{\mathrm{S}}$ \\
FR & 2 & 305.76 & 152.88 & 58800 & $0.00001^{\mathrm{S}}$ \\
PS & 2 & 0.18 & 0.09 & 34.62 & $0.00001^{\mathrm{S}}$ \\
MC*FR & 4 & 0.58 & 0.145 & 55.78 & $0.00001^{\mathrm{S}}$ \\
MC*PS & 4 & 0.11 & 0.0275 & 10.58 & $0.00001^{\mathrm{S}}$ \\
FR*PS & 4 & 0.10 & 0.025 & 9.62 & $0.00001^{\mathrm{S}}$ \\
MC*FR*PS & 8 & 0.15 & 0.0188 & 7.23 & $0.00001^{\mathrm{S}}$ \\
Error & 27 & 0.07 & 0.0026 & & \\
Total & 53 & 307.63 & & & \\
\hline
\end{tabular}

Keynote:

MC - Moisture content; FR - Feed rate; PS - Peeling speed; DF- Degree of freedom;

SS - Sum of squares; MS - Mean of squares; S - Significant; NS - Not significant

The percent damage increased from $7.5 \%$ to $13.5 \%$ with an increase in moisture content and increase in feed rate as shown in Fig. 9. [1] observed a maximum material loss of Ginger at $6.15 \%$ when the outer drum speed was $25 \mathrm{rpm}$, inner drum speed of $45 \mathrm{rpm}$ and peeling duration of 15 minutes when the drum load was constant at $6 \mathrm{~kg}$ of Ginger. At same time, the percent damage increased from $6.3 \%$ to $3.4 \%$ with an increase in peeling speed and increase in moisture content as shown in Fig. 10. [5] reported a substantial increase of flesh loss of Ginger when the speed was increased from 65 to $85 \mathrm{rpm}$.

Also, percent damage decreased from $14.4 \%$ to $6.9 \%$ with a decrease in feed rate and a decrease in peeling speed as shown in Fig. 11. [6] reported a material loss of $3.27 \%$ in an abrasive brush type Ginger peeling machine when the peeling efficiency was $85.56 \%$.

In Table 3, the analysis of variance (ANOVA) proved that the interaction of moisture content, feed rate and peeling speed had significant effect on percent damage at $\mathrm{p}<0.05$ level. 


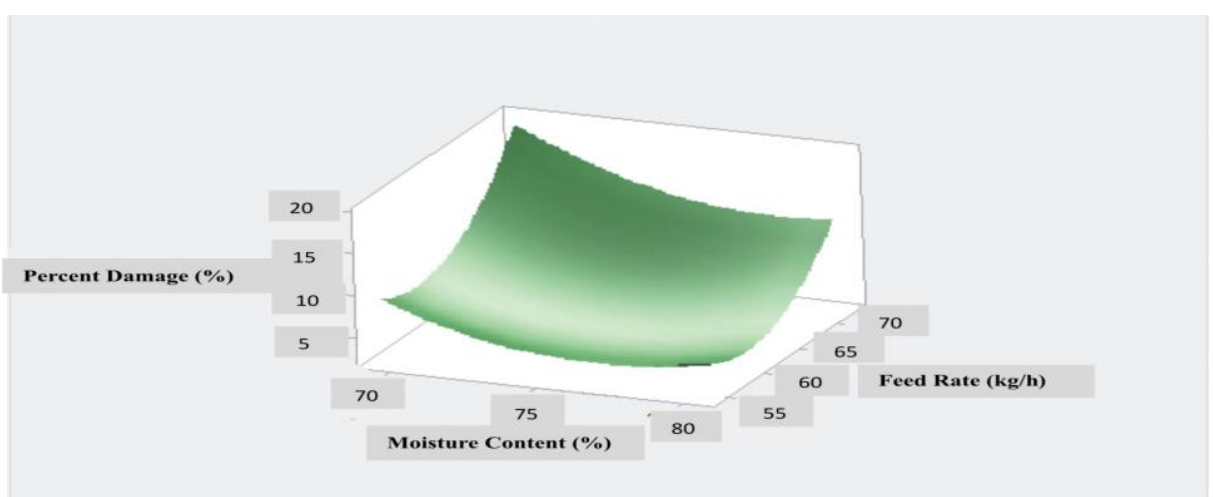

Fig. 9. Surface plot of interaction of moisture content and feed rate on percent damage

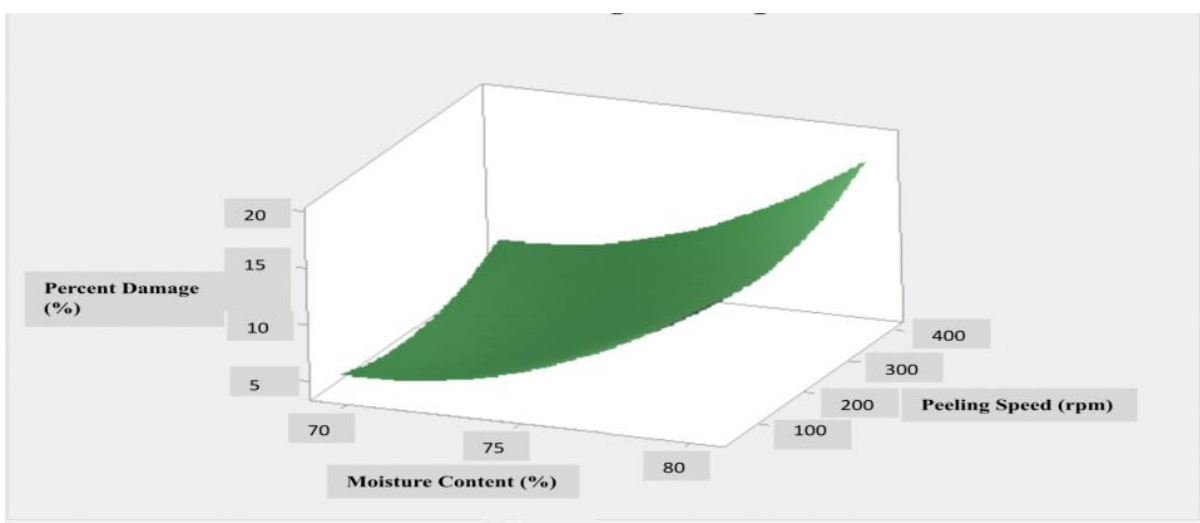

Fig. 10. Surface plot of interaction of moisture content and peeling speed on percent damage

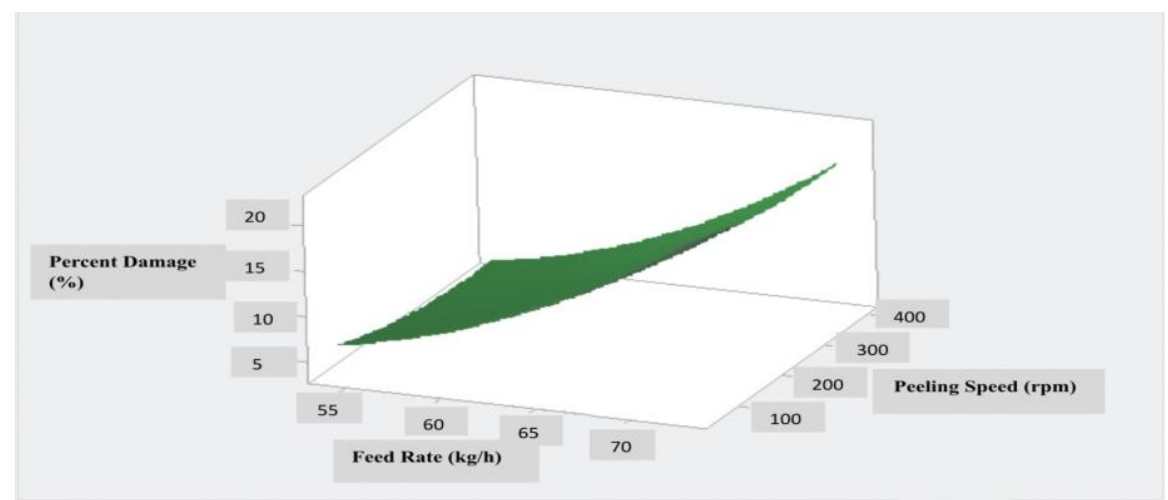

Fig. 11. Surface plot of interaction of feed rate and peeling speed on percent damage 
Tab 3. ANOVA for the effects of moisture content, feed rate and peeling speed on percent damage

\begin{tabular}{llllll}
\hline Source of Variation & DF & SS & MS & F-value & P-value \\
\hline MC & 2 & 84.94 & 42.47 & 151.68 & $0.00001^{\mathrm{S}}$ \\
FR & 2 & 291.34 & 145.67 & 520.25 & $0.00001^{\mathrm{S}}$ \\
PS & 2 & 3.74 & 1.87 & 6.68 & $0.0044^{\mathrm{S}}$ \\
MC*FR & 4 & 104.84 & 26.21 & 93.61 & $0.00001^{\mathrm{S}}$ \\
MC*PS & 4 & 4.99 & 1.25 & 4.46 & $0.00676^{\mathrm{S}}$ \\
FR*PS & 4 & 3.60 & 0.90 & 3.21 & $0.02802^{\mathrm{S}}$ \\
MC*FR*PS & 8 & 14.06 & 1.76 & 6.29 & $0.00013^{\mathrm{S}}$ \\
Error & 27 & 7.58 & 0.28 & & \\
Total & 53 & 526.20 & & & \\
\hline
\end{tabular}

Keynote:

MC - Moisture content; FR - Feed rate; PS - Peeling speed; DF- Degree of freedom;

SS - Sum of squares; MS - Mean of squares; S - Significant; NS - Not significant

\section{CONCLUSIONS AND RECOMMENDATION}

\section{Conclusions}

The following conclusions can be drawn based on the results of this study:

1. A motorized Ginger rhizomes peeling machine made from readily available materials was designed and developed. The machine is cheap and within the buying capacity of local farmers.

2. Peeling efficiency increased from $82.3 \%$ to $88.5 \%$ with an increase in moisture content from $70 \%$ to $80 \%$, a decrease in feed rate from $73 \mathrm{~kg} / \mathrm{h}$ to $54 \mathrm{~kg} / \mathrm{h}$ and an increase in peeling speed from $230 \mathrm{rpm}$ to $300 \mathrm{rpm}$.

3. Peeling capacity increased from $2.4 \mathrm{~kg} / \mathrm{h}$ to $1.64 \mathrm{~kg} / \mathrm{h}$ with an increase in moisture content from $70 \%$ to $80 \%$, a decrease in feed rate from $73 \mathrm{~kg} / \mathrm{hto} 54 \mathrm{~kg} / \mathrm{h}$ and an increase in peeling speed from $230 \mathrm{rpm}$ to300 rpm.

4. Percent damage increased from $6.3 \%$ to $14.4 \%$ with a decrease in moisture content from $80 \%$ to $70 \%$, an increase in feed rate from $54 \mathrm{~kg} / \mathrm{h}$ to $73 \mathrm{~kg} / \mathrm{h}$ and an increase in peeling speed from $230 \mathrm{rpm}$ to $300 \mathrm{rpm}$.

5. The interaction of moisture content, feed rate and peeling speed had significant effect on peeling efficiency, peeling capacity and percent damage at $\mathrm{p}<0.05$ level.

\section{Recommendation}

For a maximum peeling efficiency, peeling capacity and minimum percent damage, an optimum moisture content of $75 \%$, feed rate of $67 \mathrm{~kg} / \mathrm{h}$ and peeling speed of $270 \mathrm{rpm}$ were recommended for use.

\section{REFERENCES}

[1] Jayashree, E. and R.Visvanathan. 2014. Studies on Development of Concentric Drum, Brush Type Ginger Peeler.Agriulture Mechanization in Asia, Africa and Latin America. 45(4). pp. 82-87. 
[2] Onu, L.T. and G.I. Okafor. 2002. Effect of Physical and Chemical Factor Variations on the Efficiency of Mechanical Slicing of Nigerian Ginger. Journal of Food Engineering. 56. pp. 43-47.

[3] Simonyan, K.J., Ehiem, J.C., Eke, A. B., Adama, J. C. and D. A. Okpara. 2013. Some physical Properties of Ginger Varieties. Journal of Applied Agricultural Research, 5(1): pp. 73-79.

[4] Pearce, J.M., Grafman, L., Bot, C. and F.Hashmi. 2008. Ginger Processing. http//www.appropedia.org. Accessed $4^{\text {th }}$ April,2009.

[5] Agrawal, Y.C., Hiran, A. and A.S. Galundia.1987. Ginger Peeling Parameters. Agricultural Mechanization in Asia, Africa and Latin America, 18(2). pp. 59-62.

[6] Ali, Y.G.C., Jain, S., Kapdi, S., Agrawal, Y.C. and S. Bhatnagar.1991. Development of Brush Type Ginger Peeling Machine. Agriculture Mechanization in Asia, Africa and Latin America, 22 (2). pp.71-73.

[7] Singh, K.K. and B. D. Shukla.1995. Abrasive Peeling of Potatoes. Journal of Food Engineering. 26:b. pp.431-442.

[8] Balami, A.A., Dauda S.M., Mohammed, I.S., Agunsoye, J.K., Abu, H., Abubakar, I. and D. Ahmad. 2016. Design and Fabrication of a Cocoyam (Colocasia esculenta) Peeling Machine. International Food Research J. 23(Suppl). S65 - S70

\title{
OCENA PERFORMANSI MAŠINE SA MOTOROM ZA LJUŠTANJE GINGER KORENA
}

\section{Chimdi Godswill Arocha1 ${ }^{1}$, Kayode Joshua Simonyan ${ }^{1}$, Tosin Paul ${ }^{1}$}

\author{
${ }^{1}$ Department of Agricultural and Bioresources Engineering \\ Michael Okpara University of Agriculture, Umudike, Abia State, Nigeria.
}

Sažetak: Dizajnirana, razvijena i testirana mašina sa motorom za ljuštenje korena đumbira u količini od $5 \mathrm{~kg}$ (Ginger) (Zingiber Officinale Roscoe).

Ispitivanje obuhvatilo tri vrednosti: sadržaja vlage $(70 \%, 75 \%$ i $80 \% \mathrm{wb})$, brzine dodavanja ( $54 \mathrm{~kg} / \mathrm{h}, 68 \mathrm{~kg} / \mathrm{h} \mathrm{i} 73 \mathrm{~kg} / \mathrm{h})$ i broja obrtaja rotora sa sečivom za ljuštenje korena (230 o/min, $270 \mathrm{o} / \mathrm{min}$ i $300 \mathrm{o} / \mathrm{min})$, za ocenu performansi mašine. Trofaktorski eksperiment $(3 \times 3 \times 3)$, sistem randomizovani kompletni blok dizajn (SRKBD) sa dva ponavljanja, korišćen za proučavanje efekata i interakcija tri faktora (sadržaj vlage, brzina uvlačenja krtole i brzina ljuštenja) na parametre performansi (efikasnost, kapacitet i $\%$ oštećenja) Ginger korena. Odnos između parametara performansi i faktora uticaja utvrđen je korišćenjem višefaktorskog dizajna i metode određene površine za grafičke analize.

Studija je pokazala da se efikasnost ljuštenja korena đumbira povećala sa $82,3 \%$ na $88,5 \%$ sa promenom sadržaja vlage sa $70 \%$ na $80 \%$, smanjenjem brzine punjenja od 73 $\mathrm{kg} / \mathrm{h}$ na $54 \mathrm{~kg} / \mathrm{h}$ i povećanjem broja obrtaja rotora za ljuštenje od $230 \mathrm{o} / \mathrm{min}$ na $300 \mathrm{o} / \mathrm{min}$.

Kapacitet ljuštenja korena je povećan od $2,4 \mathrm{~kg} / \mathrm{h}$ na $11,64 \mathrm{~kg} / \mathrm{h}$ uz povećanje sadržaja vlage od $70 \%$ na $80 \%$, smanjenjem količine punjenja prijemnog koša od $73 \mathrm{~kg} / \mathrm{h}$ na 54 $\mathrm{kg} / \mathrm{h}$ i povećanjem brzine rotora za ljuštenje od $230 \mathrm{o} / \mathrm{min}$ na $300 \mathrm{rpm}$.

Oštećenje (\%) korena đumbira (Ginger) je povećano sa 6,3\% na 14,4\% sa smanjenjem sadržaja vlage od $80 \%$ na $70 \%$ i sa povećanjem brzine dodavanja (punjenje) masom korena sa $54 \mathrm{~kg} / \mathrm{h}$ na $73 \mathrm{~kg} / \mathrm{h}$, i povećanjem broja obrtaja rotora sa sečivom za ljuštenje Ginger korena od $230 \mathrm{o} / \mathrm{min}$ na $300 \mathrm{o} / \mathrm{min}$. 
Rezultat analize varijanse (ANOVA, softverski paket Minitab, ver. 17.0) pokazuje da interakcija faktora: sadržaj vlage, brzina uvlačenja i brzina ljuštenja ima značajan uticaj na efikasnost ljuštenja, kapacitet ljuštenja i procenat oštećenja Ginger korena (đumbira) na nivou tačnosti $\mathrm{p}<0,05$.

Za maksimalnu efikasnost ljuštenja, kapacitet ljuštenja i minimalni procenat oštećenja, preporučeni su: optimalni sadržaj vlage $75 \%$, brzina uvlačenja mase korena đumbira $68 \mathrm{~kg} / \mathrm{h}$ i broj obrtaja rotora sa sečivom za ljuštenje Ginger (đumbir) korena (Zingiber Officinale Roscoe) od $270 \mathrm{o} / \mathrm{min}$.

Ključne reči: Ginger koren, procena performansi, kapacitet ljuštenja, efikasnost ljuštenja.

Prijavljen:

Submitted: 07.07.2021.

Ispravljen:

Revised: $\quad 10.10 .2021$

Prihvaćen:

Accepted: 15.11.2021. 